\title{
Models of attraction of private investments into the port infrastructure
}

\author{
Elena Vasilyeva ${ }^{1 *}$ and Irina Polyakova ${ }^{1}$ \\ ${ }^{1}$ Moscow State University of Civil Engineering, 129337, 26, Yaroslavskoye Shosse, Moscow, Russia
}

\begin{abstract}
The authors set the purpose to study the models of attraction of private investments into the port infrastructure in Russia for the sake of the development of transport infrastructure of the country in general. The prospects of the port infrastructure development, the used mechanisms of public-and-private partnership in this sphere with its specifics and legal support as well as some practical examples of implementation of publicand-private partnership projects in the ports in Russia and in the world are considered.
\end{abstract}

\section{Introduction}

According to different estimates, up to $90 \%$ of the world trade turnover is carried out with the application of shipping. In this regard the existence of qualitative and effective sea infrastructure is one of the key factors of economic growth for many countries. Nearly 1 trillion US dollars was invested in world port infrastructure during the period from 1992 to 2015 against the background of the growth of volumes of the international sea trade (Figure $1)$.

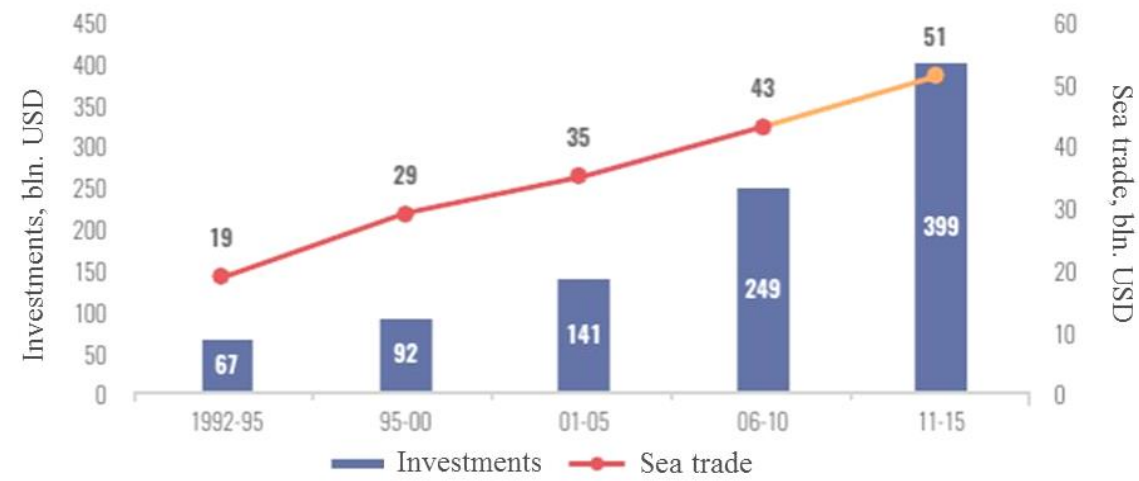

Fig 1. Dynamics of the sea trade and investments into port infrastructure in the world (according Clarkson Research; UN Comtrade; ISSA, McKinsey\&Company [1])

\footnotetext{
* Corresponding author: angela-1309.m@yandex.ru elena.chibisova metr@mail.ru
} 
Even in case of a considerable annual gain of investments of such volume it is not enough to satisfy the demand completely and to provide the appropriate rate of updating of existing and commissioning of new port capacities in the world. It is possible to cite the assessment of the Ministry of Transport of the USA as the example of negative effect of the port infrastructure deficiency: according to the calculations of the Ministry, that country loses up to 40 billion US dollars annually, because of the deficiency of deep-water ports and turns for unloading [2].

The existing deficiency and impossibility of its eliminating at the expense of budgetary funds have stimulated the liberalization of the port market which was traditionally under control of the state. For the last decades, the involvement of the private capital in this or that form became a norm in the ports infrastructure creation, as well as in many other spheres.

The similar picture is observed in Russia. The activity of the Russian sea ports has been in steady positive dynamics in the recent years. The cumulative goods turnover in ports has increased by $75 \%$ for 10 years, the capacities for transfer are more than 1 billion tons. The volumes of the processed freights in general exceeded 800 million tons in 2017. And the positive tendency remains this year. Coal, iron ore, mineral fertilizers, containers are on the rise. In spite of the fact that a certain reserve of transshipment capacities exist, their gain on 350 million tons till 2024 is provided in the development plans. The hydrocarbons: liquefied natural gas, oil and coal, act (and will act in the future) as the drivers growth of the cargo base. As for coal, its transfer is focused on the ports of the Far East, where the construction of new terminals is planned for this freight exactly. Port capacities of the Northern Sea Route will be focused on export of coal from Dickson.

Sabetta port and Dudinka port which are also specializing in the delivery of oil from new fields are tied to the Arctic traffic.

Protection of national cargo base requires further development of ports of the Northwest (first of all, the Murmansk transport hub) in order to make freights not to go to the ports of the adjacent countries. As for the Black Sea ports, the next plans for development consider Taman port as the leading one.

Thus, the port infrastructure has to develop both quantitatively, and is qualitative, in one and all directions and practically for all the freights. And if that is so, the maintenance of already operating capacities and their increase requires considerable funds [3, 4, 5].

Works by B.A. Rayzberg's, P.A. Fatkhutdinov, U. Sharp, G. Alexander, J. Bailey, M.I Knysh, B.A Perekatov, Yu.P Tyutikov, B.A. Koltynyuk, A.A. Komzolova, O.A. Maslennikova, O.A. Volkova, T.F. Ryabova, E.V. Strelkova, A.B. Brilon, A.I. Deyev, E.V. Tarasov, O.I. Volkov, X. To tails, M.L. Raz, B.B. Pozdnyakova, V.D. Shapiro, Yu. Malysheva, A. Oleneva, X. Shell, G.K. Orudzhov, I.A. Molchkova, V.N. Strok, V.G. Varnavsky, E.G. Trunin, V.A. Persianov, etc. are devoted to the matters of investments into the port infrastructure development. However, the relevance of the matter of the attraction of investments into the port infrastructure of the country is still obvious.

\section{Methods and Models}

In the conditions of the budgetary restrictions it is not possible to rely on the state money. The attraction of private funds for the port infrastructure development has some restrictions too, that is connected with the law on the seaports, which limits the private ownership for the facilities in this sphere. But the use of the mechanism of public-and-private partnership (PPP) for financing is possible within the current legislation. As the result there is a mutually advantageous alliance of interests: the state party is engaged in financing of the life support systems of port (safety, navigation, communication), business is engaged in financing of infrastructure. 
Nowadays various forms of involvement of the private capital into the activity of seaports can be found in the world practice. It is the most expedient to make their tipologization from the point of view of the basic elements of relationship of the state and the private sector within the port activity: regulation, property and operating. Regulatory activity includes control of the law enforcement, licensing, tariffing, control of the competition, etc. The role of the "owner" means the direct possession of the port infrastructure and the primary investment activities. Operational function means direct ensuring the movement of goods/passengers through the port and the implementation of the indirect activity. Taking into account these functions it is possible to distinguish four models of the port infrastructure management (Table 1).

Table 1. Models of the involvement of the private capital into the port infrastructure (according to: Baird; Gunyadin)

\begin{tabular}{|c|c|c|c|}
\hline \multirow{2}{*}{$\begin{array}{c}\text { Model of the port management (from } \\
\text { the point of view of involvement of } \\
\text { the private sector) }\end{array}$} & \multicolumn{3}{|c|}{ Subject of relationship } \\
\hline & regulation & property & operating \\
\hline public & public & public & public \\
\hline operating & public & public & private \\
\hline managerial & public & public /private & private \\
\hline private & public /private & private & private \\
\hline
\end{tabular}

The general logic of this classification is based on the degree of the involvement of the private partner. The most limited model is the "operational" model, within which the private sector is involved only into rendering final services. The following stage is the involvement of the private sector into the business processes. Regulatory function in most cases remains public. There are only few exceptions, such as Great Britain, where there is no specialized regulatory department. Till 1980th perfect public model of the port infrastructure management dominated in the world, the private sector actually was not attracted. Initial mass attraction of the private sector was carried out at the expense of the mechanism of full privatization in the 1980th in Great Britain.

At the same time the use of the mechanism of privatization is still rather limited. For many countries the involvement of the private sector as the operator became the alternative of privatization, such form was especially demanded till the middle of the 1990th. In the same decade different application of the schemes of partial redistribution of the port property in favour of the private sector via the mechanisms of public-and-private partnership began to gain steam [2].

The same typology can be subdivided in addition from the point of view of possession of various types of the port assets (Table 2).

Table 2. Models of involvement from the point of view of possession of the port assets (according to Public Private Infrastructure Advisory Facility, PPIAF [7])

\begin{tabular}{|c|c|c|c|c|}
\hline \multirow{2}{*}{$\begin{array}{c}\text { Model of } \\
\text { management }\end{array}$} & \multirow{2}{*}{$\begin{array}{c}\text { Realization } \\
\text { mechanism }\end{array}$} & $\begin{array}{c}\text { all-port } \\
\text { infrastructure }\end{array}$ & $\begin{array}{c}\text { Subject of relationship } \\
\text { infrastructure } \\
\text { (equipment, } \\
\text { arehouses, moorings) }\end{array}$ & labour power \\
\cline { 3 - 5 } & ----- & public & public & public \\
\hline public & quasi-PPP & public & public & private \\
\hline operating & PPP & public & private & private \\
\hline managerial & PPP/privatization & private & private & private \\
\hline private & & &
\end{tabular}

The most common form of attraction of the private sector into port infrastructure is the "managerial" model ("landlord model"). It is specified in some sources, that up to $90 \%$ of 
all the port projects of the last twenty years belong to this model. The key mechanism of the realization of this model is the public-and-private partnership, from O\&M contracts to so called "greenfield" concessions.

Taking into account the strategic importance of many ports, the PPP mechanisms represent the most balanced instrument of the involvement of the private sector into the port infrastructure management. On the one hand, PPP allows to attract the private capital and to introduce a commercial incentive due to distribution of responsibility and risks, and on the other hand it neutralizes the possibility of negative consequences of full privatization (for example, of the use of a land plot not for its initial appointment).

In general, all the PPP schemes can be divided according to two characteristics:

- the status of readiness of the infrastructure;

- the ownership right after end of the agreement. The status of readiness means the division into two groups:

1) already existing facilities ("brownfield"), which, as a rule, need to be reconstructed and/or expanded;

2) planned facilities ("greenfield"), which are only to be constructed.

The comparison of the main contract PPP schemes for the port infrastructure, based on these characteristics as well as the distribution of operational and investment responsibility is presented in Table 3 .

In general, all the PPP schemes can be divided according to two characteristics:

- the status of readiness of the infrastructure;

- the ownership right after end of the agreement. The status of readiness means the division into two groups:

1) already existing facilities ("brownfield"), which, as a rule, need to be reconstructed and/or expanded;

2) planned facilities ("greenfield"), which are only to be constructed [8].

The comparison of the main contract PPP schemes for the port infrastructure, based on these characteristics as well as the distribution of operational and investment responsibility is presented in Table 3.

Table 3. The main PPP schemes in comparison (according to PPIAF [7])

\begin{tabular}{|c|c|c|c|c|c|}
\hline $\begin{array}{c}\text { Status of the } \\
\text { infrastructure }\end{array}$ & $\begin{array}{c}\text { Scheme of } \\
\text { involvement }\end{array}$ & $\begin{array}{c}\text { Operating } \\
\text { activities }\end{array}$ & Investments & $\begin{array}{c}\text { Final } \\
\text { property }\end{array}$ & $\begin{array}{c}\text { Term, } \\
\text { years }\end{array}$ \\
\hline \multirow{4}{*}{ Brownfield } & Privatization & private & private & private & ----- \\
\cline { 2 - 6 } & $\begin{array}{c}\text { Contract for } \\
\text { management }\end{array}$ & private & public & public & $3-7$ \\
\cline { 2 - 6 } Greenfield & $\begin{array}{c}\text { Rehabilitate, } \\
\text { Operate, Tranfer } \\
\text { (ROT) }\end{array}$ & private & public & public & $8-15$ \\
\hline & $\begin{array}{c}\text { Build, Operate, } \\
\text { Transfer (BOT) }\end{array}$ & private & private & public & $20-30$ \\
\cline { 2 - 6 } & $\begin{array}{c}\text { Build, Own, } \\
\text { Operate (BOO) }\end{array}$ & private & private & private & $20-30$ \\
\hline
\end{tabular}

Regardless of the form, involving the private capital into the port infrastructure the state pursues two main objectives: the increase in the efficiency of final services and the optimization of budget expenditure $[8,9]$.

\section{Results}

The analysis of practice allowed to reveal some tendencies of the sea port infrastructure development in Russia. These tendencies can be divided into two groups: external 
(determined by the development of the world and national economy) and internal (peculiar to the port industry) [10].

To external factors include, first of all, the stagnating dynamics of the economic growth in Russia in the recent years, the goods turnover growth in the world and in Russia, the growth of the need for capacities of the port infrastructure, determined by that growth, strengthening of the competition among the separate facilities of the port infrastructure (ports and terminals), whole countries and sea pools for the service of cargo streams.

The internal factors include the trend of the change of geography, type of constructions of the port infrastructure and the sent freights, the priorities of public policy in the field of the sea port infrastructure development, dynamics of the port infrastructure capacity, change of the place of Russia in the international goods turnover, served by sea ports.

The analysis of data of the Russian Union of Industrialists and Entrepreneurs allows to claim, that two options of the sea port infrastructure development are applied now:

1) the target investments into the ports development, tied to the cargo base of the investor;

2) investments into the specialized and/or multi-grocery stevedoring capacities, which are

not connected with the specific cargo owner.

In the first case the large mining companies, which generate steady freight traffic, build through barrier-free logistic chains at the joint "port - railroad". One of the main problems, which investors face, is the insufficiency of the railway approaches and the port logistic infrastructure [11]. It is difficult for Russian ports to be transformed to any effective knots in global chains of deliveries without large-scale construction or reconstruction of land logistic infrastructure (creation of port clusters, port industrial parks).

In the second case the development of ports allows to provide a wide range of clients with port services. However the deficiency of the development of the adjacent transport and logistic and power infrastructures remains in this segment too [12].

Realization of the model of the attraction of target investments into the ports development is caused by the shortage of modern port capacities (on the one hand), and by the requirement of the private branch companies consignors in the increase in the efficiency of export of their production (on the other hand) [13]. Thus, they are interested in steady functioning and development of seaports. On the one hand, these companies take shares of the stevedoring companies of seaports and become their owners. For the large exporters it gives the chance to really cut export expenses and also to considerably reduce risks of not export of the production. On the other hand, the companies (as a rule, they are large industrial financial groups) are extremely interested in the sea ports development, they are ready to put further investments into the development of infrastructure facilities of sea ports [14].

The authors of the article also studied the opinion of the analysts of the INFRAONE Company $[10,11]$ on the priorities of interests of the private investor and the state in the infrastructure projects on the water transport (Table 4).

Such objects as seaports, hydraulic engineering constructions, terminals and navigation are compared for descriptive reasons. As we can see, the private investors are attracted to the sea ports by the high possibility of receiving super profit as well as by high traffic and respectively great demand. There is one more important nuance. In the 2000th the state undertook financing of the life support systems of ports, including access railway tracks, without which any port cannot exist. Nowadays, when there are less budgetary funds, the private investor has to participate in financing of the accompanying infrastructure too. If, for example in the Far East port the corresponding infrastructure is being developed for coal shipment (including moorings, terminals, etc.), then limited carrying opportunities of the railroad from Kuzbass or Khakassia, where coal is extracted, can become a "bottleneck". The experts suppose, that there has to be an integrated approach already at the stage of justification of the project, facility, its construction and maintenance. We cannot 
exclude any component from the sheaf "port - freight - the way of delivery of freight". Moreover, synchronization of works at all stages is provided during consideration of the project as whole. That means their timely performance and finishing in order to provide the return of invested funds. And thus the private concession initiative, which allows the investor to create project conditions, is attractive. In general the matter of synchronization of the work performance within the PPP projects demands legal completion, as now all the risks on violations fall on the concessionaire more precisely [15].

Table 4. Combination of interests of the private and public parties in the infrastructure projects

\begin{tabular}{|c|c|c|c|c|c|}
\hline \multicolumn{2}{|r|}{ Subject } & Sea ports & $\begin{array}{l}\text { Hydraulic } \\
\text { structure }\end{array}$ & $\begin{array}{l}\text { Freight } \\
\text { terminal }\end{array}$ & Navigation \\
\hline \multirow{3}{*}{$\begin{array}{l}\text { Importa } \\
\text { nt for } \\
\text { the } \\
\text { private } \\
\text { investor }\end{array}$} & making super profit & high & low & $\begin{array}{l}\text { less than } \\
\text { medium }\end{array}$ & low \\
\hline & traffic / demand & high & medium & high & medium \\
\hline & $\begin{array}{c}\text { extent of the branch } \\
\text { examination }\end{array}$ & high & $\begin{array}{l}\text { moderately } \\
\text { high }\end{array}$ & high & $\begin{array}{c}\text { moderately } \\
\text { high }\end{array}$ \\
\hline \multicolumn{2}{|c|}{ Term of the project start, years } & $\begin{array}{c}\text { more than } \\
1.5\end{array}$ & more than 1.5 & $1 \ldots 1.5$ & about 1 \\
\hline \multicolumn{2}{|c|}{ Investment cost } & $\begin{array}{c}\text { moderately } \\
\text { high }\end{array}$ & $\begin{array}{l}\text { moderately } \\
\text { high }\end{array}$ & medium & $\begin{array}{l}\text { less than } \\
\text { medium }\end{array}$ \\
\hline \multirow{3}{*}{$\begin{array}{l}\text { Important } \\
\text { for the } \\
\text { state }\end{array}$} & $\begin{array}{c}\text { participation of } \\
\text { the budget }\end{array}$ & $\begin{array}{l}\text { less than } \\
\text { medium }\end{array}$ & medium & minimal & medium \\
\hline & reputation effect & $\begin{array}{c}\text { moderately } \\
\text { positive }\end{array}$ & neutral & $\begin{array}{c}\text { moderately } \\
\text { negative }\end{array}$ & neutral \\
\hline & political effect & $\begin{array}{l}\text { moderately } \\
\text { high }\end{array}$ & high & high & medium \\
\hline
\end{tabular}

The national transport infrastructure, including ports, draws attention of foreign investors [16, 17]. But their participation is possible only in case of the approval of Government commission on foreign investments. And the bureaucracy with the check of the foreign investor with which the participants of the PPP project are indignant, is proved if we consider, that it is about the sea port, which is a strategic object $[18,19]$. In the Russian practice there is already an example of attraction of financial resources of specific investors into the projects of the International Transport Companies "Primorye-1" and "Primorye-2". The Chinese investors practically had no real competitors. How correct was the practice of the involvement of foreign investors within the private concession initiative as the only one possible? Such unreasonably low level of the competition will hardly get approvals of Russian Federal Antimonopoly Service (FAS) [15].

As for the example of the involvement of the same Chinese investors into the port infrastructure, the construction project of the deep-water area of the sea port "Arkhangelsk" has been presented lately. Without going into details of the project it should be noted, that it will be implemented on the basis of PPP with the use of the mechanism of the private concession initiative [20]. The Chinese company acts as the strategic partner. Negotiations, the corresponding the procedures and checks are being conducted and being made out since 2016. The relevant issue in the conditions of the budgetary restrictions is how to combine the expedited procedure of the involvement of the foreign investor into infrastructure and its passing through the Government commission. This issue demands additional study.

\section{Discussion}

As for the Russian practice, there is a debatable matter. If we consider sea port as the subject to concession, should we consider it to be one lot or it is possible to make several 
lots. The zones connected among themselves technologically (sea, railway, logistic) are allocated. It allows to divide the project into lots. But as the responsibility zones those lots will be poorly connected. At the same time for the bank, which credit such a project, its appeal will decrease.

There are heated discussions on such a new tool of PPP as the investment harbor fee. Its analog is the harbor fee, but it is raised not for services and it is spent not on the current purposes, but on the infrastructure development. It can be considered as the instrument of the investments return. The experts note, that this collecting is suitable for the return of means from small projects. The advantage of such mechanism is its security, but on the other hand any really great sums do not circulate through it [21]. Besides, the Ministry of Finance has not approve any method of calculation of this collecting yet.

In general, the problems of PPP are, first of all, the financing problems. But the matters of legal regulation are not less relevant.

\section{Conclusion}

To draw the conclusion it is necessary to recognize that despite the appeal of the PPP projects in ports for its participants (both parties) they still did not receive great development in Russia. The matter is that the ports have developed only at the expense of state for too long. But nowadays the private funds are ready to participate in the port infrastructure development.

Regardless of the form, while involving the private capital into port infrastructure the state pursues two main objectives, they are the increase in the efficiency of final services and the optimization of budget expenditure. In this regard, as well as in other spheres, the matter of economic effect of the involvement of the private capital is especially relevant. The analysis of world and domestic practice proves that the involvement of the private sector (whether it be privatization or PPP) positively influences the economic efficiency of the ports. The solution of the problems, existing in Russia in this sphere, can be reached just at the expense of the PPP mechanism and in some cases by privatization of hydraulic structure, which are under economic authority of the state unitary enterprises.

\section{References}

1. Clarkson Research, UN Comtrade, ISSA, Trade Data Analytics and Visualization, https://www.mckinsey.com/business-functions/mckinsey-analytics/our-insights [Digital resource. Access Mode: 30.09.2018] (McKinsey\&Company, 2018)

2. East Economic Forum, National PPP Centre. Attraction of private investments and competences for the development of infrastructure of seaports in Russia (Russia, Vladivostok, 2017)

3. H.T. Phuong, E. Scherbina, Basic research, 7, 373-378

4. V. Carbone, Maritime Policy \& Management 30 (4), 305-320 (2003)

5. N. Evreenova, World of Transport and Transportation 5, 170-176 (2014)

6. P.B. Richman, Private Investments (Access Mode: 30.09.2018) DOI: 10.1097/01.EEM.0000298839.52903.d5 (2007)

7. Public Private Infrastructure Advisory Facility, The State of Infrastructure PublicPrivate Partnerships in Countries Affected by Fragility, Conflict or Weak Institutions (USA, Washington, 2018)

8. Y.M. Bandara, Hong-Oanh Nguyen, Chen S-L, Asian Journal of Shipping and Logistics 29(2),187-206 
9. P. C. Millán, J. Baños-Pino, I. Mateo-Mantecón, Essays on Port Economics. The Effect of Port Infrastructures on Regional Production (Springer, 2010)

10. InfraONE Company, New Infrastructure markets and unimproved opportunities of old ones. What investment potential does private capital have and what restrictions does it face? Analitical Review (SPIEF, St. Petersburg, 2017)

11. A. Zhundrikov, E. Galaktionova, J. Yakunina, J. Dordzhiyeva, Infrastructure of Russia: index of development (Saint-Petersburg, INFRAOne Research, 2018)

12. I.S. Bulnina, L.I. Askhatova, I.A. Kabasheva, I. Rudaleva, Mediterranean Journal of Social Sciences, 6(1) (2015)

13. M. Byrne, H. Sipsas, T. Thompson, International Advances in Economic Research, 2(4), 471-476 (1996)

14. H.E Haralambides, Future Prospectives of European Ports (Green Paper on Sea Ports and Maritime Infrastructure). Charging and Financing of Port Infrastructure (Spain, Barcelona, 1998)

15. I. Polyakova, E. Vasilyeva, IOP Conference Series Earth and Environmental Science 90(1), 012121 (2017)

16. K. Stamatović, P.W. De Langen, A. Groznik, Research in Transportation Business and Management, DOI: 10.1016/j.rtbm.2018.03.006 (2018)

17. F Nistor, C Popa, R Gavra, Scientific Bulletin of Naval Academy, XXI, 163-167 (2018)

18. A. Mottaeva, MATEC Web of Conferences, 106, 08071 (2017)

19. C. Woudsma et al., Transportation Research Procedia, 12, 474-488 (2016)

20. I. Polyakova, E. Vasilyeva, N. Vorontsova, IOP Conference Series Earth and Environmental Science 90(1), 012136 (2017)

21. O. Karpovich, A. Shlafman, IOP Conference Series Earth and Environmental Science 90(1), 012115, DOI: 10.1088/1755-1315/90/1/012115 